\title{
Patient with lung adenocarcinoma manifesting as an unusual migratory pulmonary infiltration
}

\author{
Kohei Fujita, ${ }^{1}$ Jaegi Shim, ${ }^{2}$ Koichi Nakatani, ${ }^{1}$ Tadashi Mio ${ }^{1}$
}

${ }^{1}$ Department of Respiratory Medicine, National Hospital Organization Kyoto Medical Center, Kyoto, Japan ${ }^{2}$ Department of Nephrology, National Hospital Organization Kyoto Medical Center, Kyoto, Japan

\section{Correspondence to} Dr Kohei Fujita, kf0411@kuhp.kyoto-u.ac.jp

Accepted 20 July 2015

\section{DESCRIPTION}

A 77-year-old woman with no history of smoking or dust exposure was admitted to our hospital for a cough lasting more than 2 months. She had taken no medication during the past years. Chest X-ray at the first visit showed bilateral upper lung reticular opacity. Chest CT scan showed bilateral upper and middle lobe ground glass opacity (GGO) with partial mixed consolidations and nodules (figure $1 \mathrm{~A}-\mathrm{C})$. Sequential chest CT scans after 2 weeks revealed migrating GGO (figure 1D-F). Laboratory findings showed normal white cell counts $(5700 / \mu \mathrm{L})$ and $\mathrm{C}$ reactive protein levels $(0.48 \mathrm{mg} / \mathrm{dL})$. Serum markers of lung fibrosis (sialylated carbohydrate antigen KL-6, $424 \mathrm{U} / \mathrm{mL}$ and surfactant protein-D, $131 \mathrm{ng} / \mathrm{mL}$ ) also presented at normal levels. The patient had negative serological status for HIV and the interferon $\gamma$ release assay. Autoantibody tests showed no elevations of rheumatoid factor, proteinase- 3 and myeloperoxidase, as well as no antineutrophil cytoplasmic antibodies and antiglomerular basement membrane antibody.
Because the patient's radiological findings were compatible with diffuse interstitial lung disease (ILD), bronchoscopy was performed 3 weeks after the first visit. Bronchoalveolar lavage fluids showed no elevation of eosinophils. Positron-emission tomography CT scan suggested high uptake of fluorodeoxyglucose in the bilateral upper lungs in conjunction with interstitial infiltrations (figure 1G-I). Bilateral upper lungs were chosen as the target area for transbronchial lung biopsy and revealed adenocarcinoma (figure $2 \mathrm{~A}-\mathrm{C})$. Three of the $4(75 \%)$ specimens showed malignancies, which suggested interstitial infiltration as carcinomatous lymphangiosis. After diagnosing lung cancer, we used systemic corticosteroids in combination with anticancer drugs. Because bilateral interstitial infiltrations were quickly improved after steroid induction, migratory infiltrations had a feature of possible organising pneumonia caused by cancer.

Although migratory GGO of the upper lung is likely to exist in ILD, ${ }^{1-3}$ malignant disease should be considered when GGO spreads rapidly.


Figure 1 Chest $\mathrm{CT}$ at the initial visit showing bilateral upper and middle lobe interstitial infiltrations with ground glass opacity (A-C). A follow-up CT scan obtained 2 weeks later demonstrating the emerging spread of ground glass opacity with migration (D-F). A positron-emission tomography CT scan revealing a high integration of fluorodeoxyglucose in concurrence with interstitial infiltrations $(\mathrm{G}-\mathrm{I})$. 

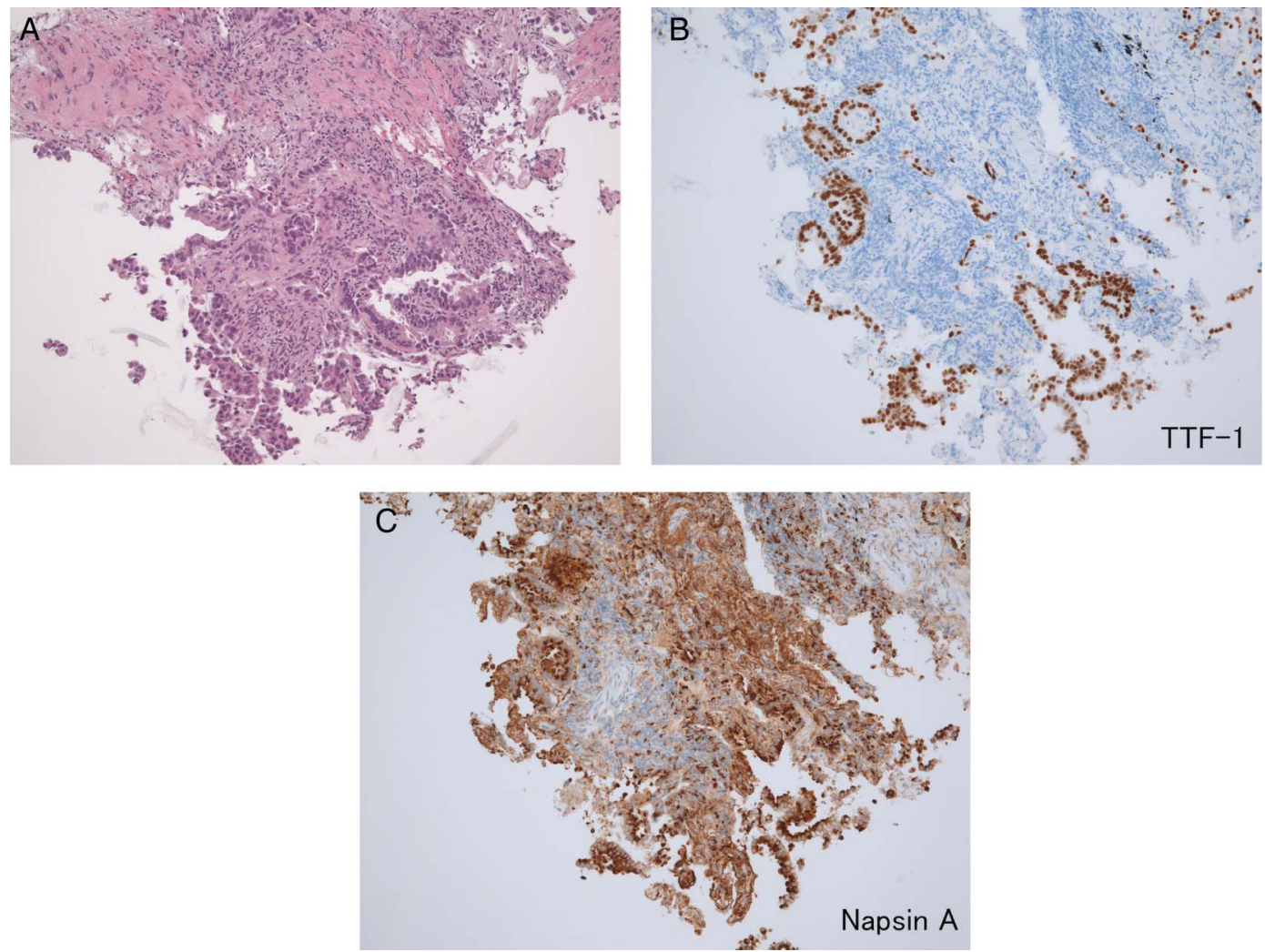

Figure 2 Transbronchial lung biopsy specimens showing malignant cells with anisokaryosis forming irregular papillary and tubular structures in H\&E-stained tissue (A). The tumours were positive for thyroid transcription factor 1 (TTF-1) and novel aspartic proteinase of the pepsin family (napsin $A)$, which are markers of adenocarcinoma originating from the lung (B and $C$ ).

\section{Learning points}

- Upper lung interstitial pneumonia with migration usually requires a differential diagnosis of some benign interstitial lung disease such as chronic eosinophilic pneumonia, hypersensitive pneumonia, organising pneumonia or drug-induced interstitial pneumonia. ${ }^{1-3}$ In the endemic area, parasitic infections are also considered.

- When lung infiltrations with GGO are rapidly worsening, physicians should be aware of the possibility of carcinomatous lymphangiosis in addition to the diseases identified above.
Contributors $\mathrm{KF}$, JS and $\mathrm{KN}$ treated and managed the patient. KF and $\mathrm{KN}$ drafted the article. TM supervised the management of the patient.

Competing interests None declared.

Patient consent Obtained.

Provenance and peer review Not commissioned; externally peer reviewed.

\section{REFERENCES}

1 Davison $A G$, Heard BE, McAllister WAC, et al. Cryptogenic organizing pneumonitis. Q J Med 1983:52:382-94

2 Miyagawa Y, Nagata N, Shigematsu N. Clinicopathological study of migratory lung infiltrates. Thorax 1991:48:233-8.

3 Izumi T, Kitaichi M, Nishimura K, et al. Bronchiolitis obliterans organizing pneumonia: clinical features and differential diagnosis. Chest 1992;102:715S-19S.

Copyright 2015 BMJ Publishing Group. All rights reserved. For permission to reuse any of this content visit http://group.bmj.com/group/rights-licensing/permissions.

BMJ Case Report Fellows may re-use this article for personal use and teaching without any further permission.

Become a Fellow of BMJ Case Reports today and you can:

- Submit as many cases as you like

- Enjoy fast sympathetic peer review and rapid publication of accepted articles

- Access all the published articles

- Re-use any of the published material for personal use and teaching without further permission

For information on Institutional Fellowships contact consortiasales@bmjgroup.com

Visit casereports.bmj.com for more articles like this and to become a Fellow 